\title{
The first crocodyliforms remains from La Parrita locality, Cerro del Pueblo Formation (Campanian), Coahuila, Mexico
}

Héctor E. Rivera-Sylva, Gerardo Carbot-Ghanona, Rafael Vivas-González, Lizbeth Nava-Rodríguez, Fernando Cabral-Valdéz

Héctor E. Rivera-Sylva

Fernando Cabral-Valdéz

Departamento de Paleontología, Museo del Desierto, Carlos Abedrop Dávila 3745, 25022, Saltillo, Coahuila, Mexico.

\section{Gerardo Carbot-Ghanona} gfcarbot@gmail.com

Museo de Paleontología "Eliseo Palacios Aguilera", Secretaría de Medio Ambiente e Historia Natural. Calzada de los hombres ilustres s/n, 29000, Tuxtla Gutiérrez, Chiapas, Mexico.

\section{Rafael Vivas-González}

Villa Nápoles 6506, Colonia Mirador de las Mitras, 64348, Monterrey, N. L., Mexico.

\section{Lizbeth Nava-Rodríguez}

Facultad de Ingeniería, Universidad Autónoma de San Luis Potosí, Dr. Manuel Nava 8, Zona Universitaria Poniente, San Luis Potosi, S.L.P., Mexico.
BOL. SOC. GEOL. MEX. 2019

VOL. 71 NO. 3

P. $727-739$

http://dx.doi.org/10.18268/BSGM2019v71n3a6

\section{ABSTRACT}

The record of land tetrapods of the Cerro del Pueblo Formation (Late Cretaceous, Campanian), in Coahuila, includes turtles, pterosaurs, dinosaurs, and crocodyliforms. This last group is represented only by goniopholidids, indeterminate eusuchians, and Brachychampsa montana. In this work we report the first crocodyliform remains from La Parrita locality, Cerro del Pueblo Formation, based on one isolated tooth, vertebrae, and osteoderms. The association of crocodyliforms, turtles, dinosaurs, and charophyte oogonia provide evidence for stagnant to fluvial environments on a delta plain with tropical climate for the Cerro del Pueblo Formation during the Late Cretaceous.

Keywords: Grocodyliforms, Globidonta, Late Cretaceous, Coahuila, Mexico.

\section{RESUMEN}

El registro de tetrápodos terrestres en la Formación Cerro del Pueblo (Cretácico tardío, Campaniano) en Coahuila, incluye tortugas, pterosaurios, dinosaurios $y$ crocodyliformes. Este último grupo está representado por goniofólididos, eusuquios indeterminados y Brachychampsa montana. En este trabajo se reportan los primeros restos de crocodyliformes de la localidad La Parrita, Formación Cerro del Pueblo, con base en un diente aislado, vértebras y osteodermos. La asociación de crocodyliformes, tortugas, dinosaurios y oogonias de cariofitas, proporcionan evidencia de ambientes fluviales en una llanura deltaica de tipo tropical para la Formación Cerro del Pueblo durante el Cretácico tardío.

Palabras clave: Crocodyliformes, Globidonta, Cretácico tardío, Coahuila, México. 


\section{Introduction}

The fossil record of land vertebrates from the Cerro del Pueblo Formation in Coahuila includes turtles, squamates, crocodyliforms, pterosaurs, and dinosaurs. The turtle record includes a pleurodire with similarities to Chedighaii, the paracryptodires Compsemys and Neurankylus, the cheloniid Mexichelys coahuilaensis, the kinosternid Hoplochelys, the trionychid Adocus, and indeterminate chelydrid, kinosternoid, and trionychid remains (Brinkman, 2014). The only squamate is "Coniophis" sp., a taxon based on vertebrae collected near Rincon Colorado (Aguillon-Martinez, 2010). Pterosaurs are represented by one indeterminate ornithocheiroid (Frey and Stinnesbeck, 2014). The dinosaur record comprises the hadrosaurids Velafrons coahuilensis and Latirhinus uistlani, the ceratopsian Coahuilaceratops magnacuerna, ankylosaurids, the dromeosaurids Tröodon and Saurornitholestes, the problematic coelurosaur Richardoestesia, tyrannosaurids, and ornithomimosaurs (Rivera-Sylva and Carpenter, 2014a, 2014b). Records of crocodyliforms in the Cerro del Pueblo Formation include indeterminate eusuchian and goniopholidid material (Rodríguez-de la Rosa and Cevallos-Ferriz, 1998), along with a skull table, two frontal bones, isolated teeth, and isolated osteoderms that Aguillon-Martinez (2010) referred to the globidontan alligatoroid Brachychampsa montana.

The material described in the present work comes from the La Parrita locality, located $54 \mathrm{~km}$ to the west of Saltillo (Figure 1), and includes fragments of a maxilla and lower jaw, vertebrae, osteoderms, and one bulbous tooth. The morphology of the tooth allows the classification as Globidonta, and thus is the second record of this clade of crocodyliforms in the Cerro del Pueblo Formation, Coahuila. The rest of the material can only be assigned as Eusuchia.

Globidonta is an alligatoroid clade characterized, at least ancestrally, by the presence of bulbous posterior teeth. Its content in recent phylogenetic analyses is redundant with that of Alligatoridae (e.g., Brochu, 2011; Skutchas et al., 2014; Salas-Gis- mondi et al., 2015; Hastings et al., 2016), but Globidonta is explicitly a stem-based group, and Alligatoridae is node-based (Brochu, 1999). Furthermore, some Late Cretaceous North American globidontans were excluded from Alligatoridae in earlier analyses (e.g., Brochu, 2004; Martin and Lauprasert, 2010), such as Stangerochampsa mccabei from the Early Maastrichtian Horseshoe Canyon Formation, southern Alberta (Wu et al., 1996); Albertochampsa langstoni from the middle Campanian Dinosaur Park Formation of southern Alberta (Erickson, 1972), and Brachychampsa reported from several sites of early Campanian through late Maastrichtian age throughout western North America (Gilmore, 191 1; Carpenter and Lindsay, 1980; Bryant, 1989; Norell et al., 1994; Williamson, 1996; Sullivan and Lucas, 2003; Monroy Mújica, 2009; Aguillon-Martinez, 2010; Irmis et al., 2013). Two species of Brachychampsa are recognized: $B$. sealeyi from the Campanian De-Na-Zin Member of the Kirtland Formation, San Juan Basin, New Mexico (Williamson, 1996); and the type species, B. montana from the Hell Creek Formation of Montana (Gilmore, 1911; Bryant, 1989; Norell et al., 1994) and possibly elsewhere in western North America.

Institutional abbreviations: CPG, Colección Paleontológica de Coahuila (Paleontological Collection of Coahuila), Museo del Desierto (MUDE), Saltillo, Coahuila, Mexico.

\section{Geological setting and paleoenvironment}

The locality of La Parrita is part of the Cerro del Pueblo Formation, which is the oldest geologic formation from the Difunta Group (Figure 2A). The Cerro del Pueblo Formation is dated between 71 and 72.5 million years old (Obradovich, 1993; Eberth et al., 2004), which indicates Campanian age. The Cerro del Pueblo Formation was deposited under marginal marine and shallow marine conditions, which were influenced by sea-level oscillations and storm events (Eberth et al., 2004). 


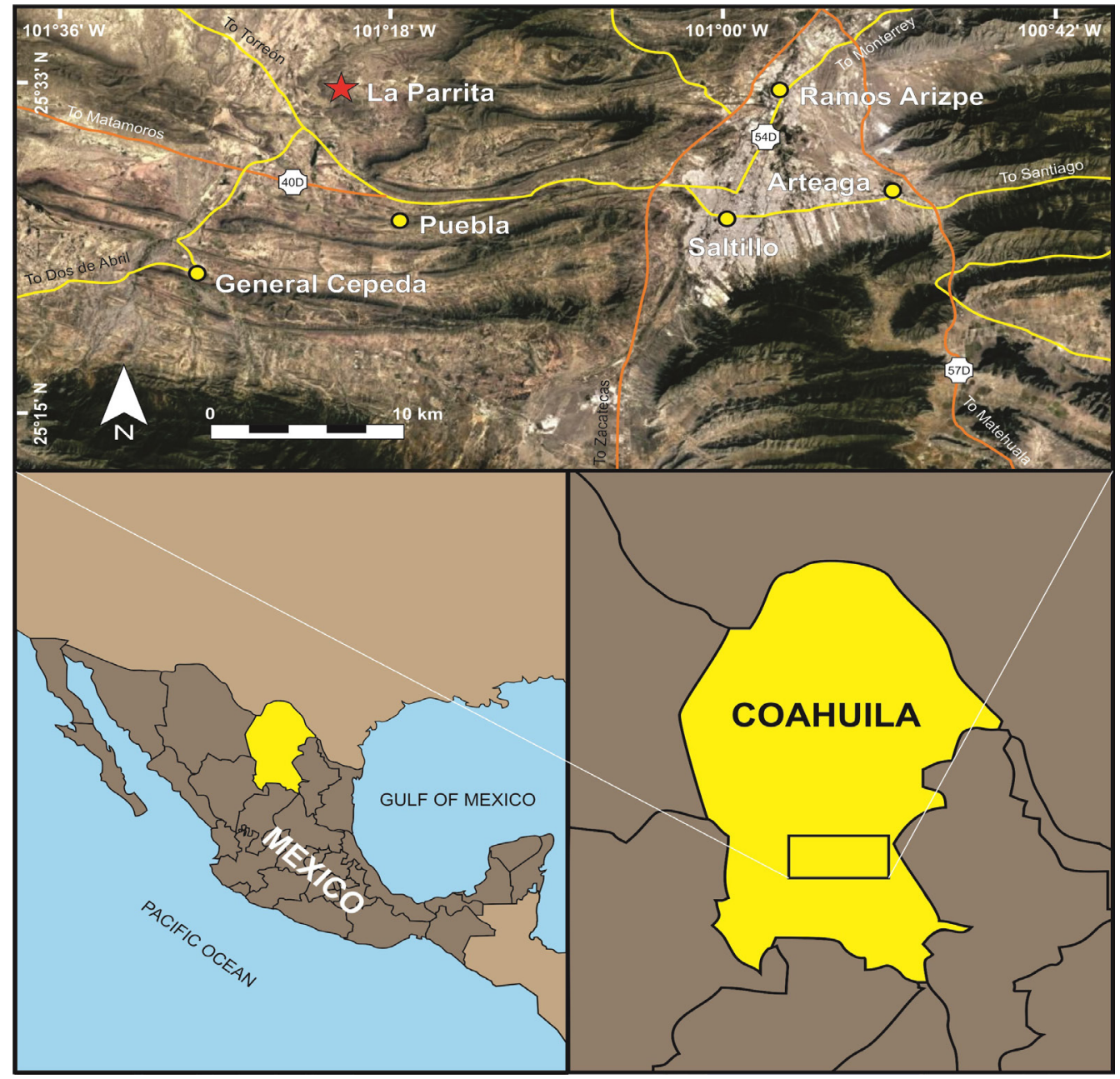

Figure 1 Location of the La Parrita locality (red star), Cerro del Pueblo Formation, Coahuila state.

The facies suggest deltaic systems with shallow flow channels, oxbow or residual lakes, bays and lagoons, coastal swamps, and wetlands with exuberant vegetation (McBride, 1974; Hill, 1988).

The stratigraphic sequence that outcrop in La Parrita locality is composed of alternating layers of sandstone, siltstone and shale (Figure 2B). At the base, it is comprised of $0.20 \mathrm{~m}$ of ochre-gray shales with greenish tonalities. Marine taxa such as the ammonite Sphenodiscus and some isolated, weathered dinosaur bones are associated with this layer. According to Eberth et al. (2004: 350352, fig.5), Sphenodiscus is present in facies 1 corresponding to the Parras Shale, which means this first layer is the base in which Cerro del Pueblo Formation is supported (Vivas-González, 2013).
Above the base follows a $0.30 \mathrm{~m}$ layer consisting of exfoliated siltstones with a high concentration of oysters of diverse size, which indicate a brackish environment. According to Stinnesbeck and Frey (2014), the Cerro del Pueblo Formation sandstone and siltstone deposits are characteristic of brackish conditions, indicated by oyster banks and abundant non-ostrean bivalves and gastropods. Above the siltstone lies a $0.90 \mathrm{~m}$ hard, massive, coarse-grained sandstone layer with high concentrations of gastropods at the top, which indicates marine costal environments (Vivas-González, 2013). A grit layer continues by $1 \mathrm{~m}$ above, with a $0.40 \mathrm{~m}$ thick concentration of gastropods lies above the grit. The next layer consists of $10 \mathrm{~m}$ of ochre-gray shale characterized 

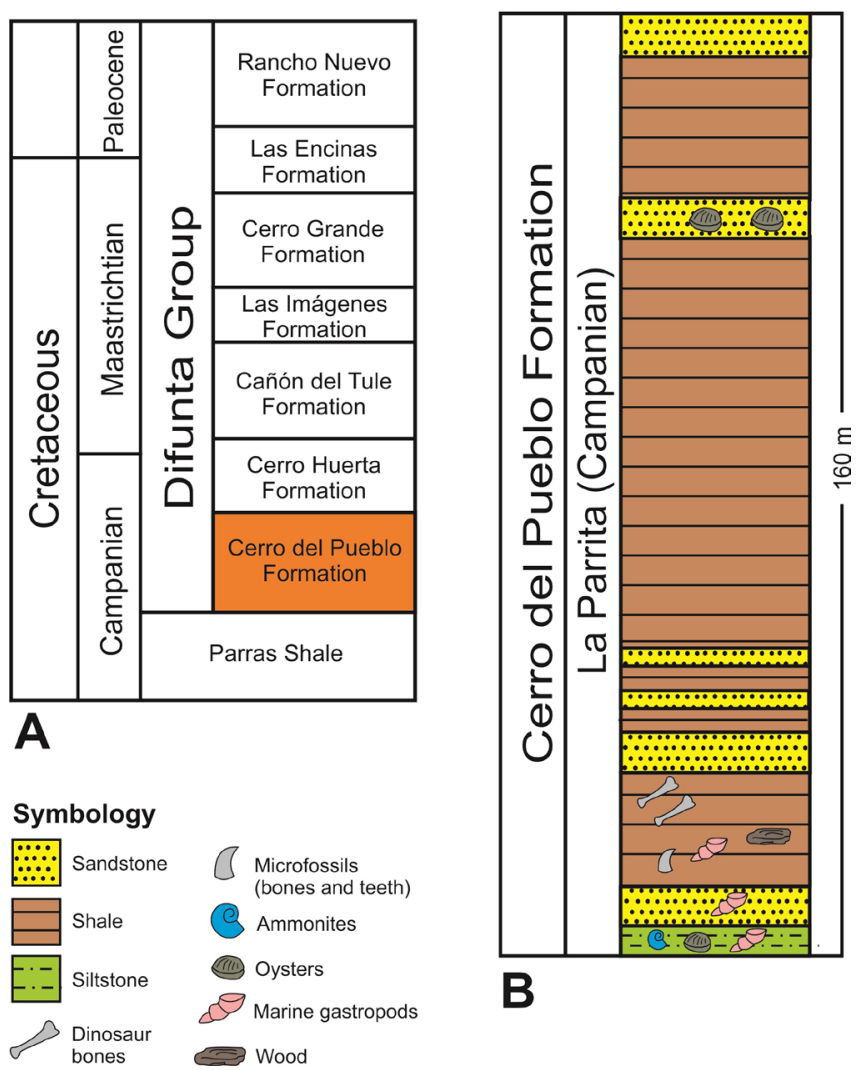

B

Figure 2 Stratigraphic chart showing the age and divisions of the Difunta Group with the stratigraphic position of the Cerro del Pueblo Formation (A), and local stratigraphy of La Parrita locality (B), showing the sequence of alternant strata (sandstone, siltstone, and shale). A large diversity of vertebrate and invertebrate fossils occurs in the second layer of shale (from the bottom).

by fossil diversity: the marine gastropods Cerithium nodosa and Lissapiopsis sp. are common, as well as oysters (Flamingostrea sp.). These mollusks represent the most common invertebrates in this shale layer (Vivas-González, 2013). Wood fragments are also present, and among vertebrate fossils, reptiles like trionychid turtles, some goniopholidids crocodyliforms, bone and teeth of dinosaurs (hadrosaurids, tyrannosaurids and dromeosaurids) are present, as well as coprolites (Vivas-González, 2013). Eberth et al. (2004: 350-352) placed this kind of fossil assemblage between facies 10-12. The assemblage is suggestive of overflooded coastal plains, and the marine and limnic faunal assemblages that coexist in this layer indicate an estuarine environment (VivasGonzález, 2013; Stinnesbeck and Frey, 2014).

The next layer consists of $0.40 \mathrm{~m}$ of massive, gray, fine-grained sandstones followed above by $0.50 \mathrm{~m}$ of dark-gray shale and again by $0.35 \mathrm{~m}$ of fine- grained sandstones (Vivas-González, 2013). The following $0.60 \mathrm{~m}$ are composed of shale, then $0.20 \mathrm{~m}$ of fractured sandstones. Above the fractured sandstone layer lie $32 \mathrm{~m}$ of shale, which is devoid of fossils. Above this shale layer, there is a $3 \mathrm{~m}$ layer of massive medium-grained sandstones with high concentrations of bivalves, referred to Inoceramus vamuxemi in the top of the layer. No other fossils are reported in this layer. The next 18 $\mathrm{m}$ of the section are formed by shales, and the last $3 \mathrm{~m}$ on the top are medium-grained sandstones. No fossils were observed or reported in both of these top layers (Vivas-González, 2013).

This alternating sediment suggests the La Parrita locality underwent a series of events related to marine regressions and transgressions during deposition, which is consistent with other localities associated with the Cerro del Pueblo Formation (Eberth et al., 2004). 


\section{Methods}

All specimens were recovered using the standard vertebrate microfossil surface collection method at the La Parrita locality. All material was collected in an area of $15 \mathrm{~m}^{2}$, in association with gastropods and fragmentary fish and turtle remains. Although the material comes from a small area, we do not speculate whether or not it comes from a single individual, despite the specimens' match in size.

The material was cleaned using brushes and needles. Measurements were obtained with a digital caliper with $0.01 \mathrm{~mm}$ accuracy. Photographs were taken with a Canon X5 digital camera, and the images were processed using Adobe Illustrator and CorelDraw X8.

\section{Systematic paleontology}

Crocodyliformes Benton and Clark, 1988

Eusuchia Huxley, 1875

Crocodylia Owen, 1842

Alligatoroidea Gray, 1844 sensu Norell et al., 1994

Globidonta Brochu, 1999

Gen. and sp. indeterminated

Material. CPC 1483, isolated posterior tooth. Locality and horizon. La Parrita is located $25^{\circ} 32^{\prime} 68.4^{\prime \prime} \mathrm{N}, 101^{\circ} 20^{\prime} 93.7^{\prime \prime} \mathrm{W}$, in the municipality of General Cepeda, Coahuila. Cerro del Pueblo Formation, Campanian, Late Cretaceous.

Description. CPG 1483 is small, labiolingually compressed and distomesialy inflated tooth crown (Figures 3A to 3C). It has fine irregular striations that radiate from the apex to the base; they are deeper at the distal side of the tooth. They lack carinae. The base of the crown is oval in outline with a maximum width of $9.2 \mathrm{~mm}$.

\subsection{EUSUGHIANS INDETERMINATED}

Material. CPC 1479, anterolateral portion of right maxilla; CPG 1480, medial fragment of right maxilla; CPG 1481, medial fragment of left maxilla; CPG 1482, fragment of left dentary; CPC 1484, paravertebral osteoderm; CPG 1485, paravertebral osteoderm; CPC 1486, lateral dorsal osteoderm; CPC 1487, lateral dorsal osteoderm; CPG 1489 dorsal vertebra; CPG 1490, vertebra with uncertain position.

Locality and horizon. The La Parrita site is located $25^{\circ} 32^{\prime} 68.4^{\prime \prime} \mathrm{N}, 101^{\circ} 20^{\prime} 93.7^{\prime \prime} \mathrm{W}$, in the municipality of General Cepeda, Coahuila. Cerro del Pueblo Formation, Campanian, Late Cretaceous.

Description. CPG 1479 is a fragment that corresponds to an anterolateral portion of the right maxilla (Figures 4A and 4B). The external surface is ornamented with pits and grooves. The palatinal surface is smooth and slightly concave, with two vascular foramina. Two alveoli are present. One of them still contains a root of a $6.4 \mathrm{~mm}$ diameter circular tooth. The other alveolus is badly preserved, but is smaller. Between both alveoli is present a well-developed depression.

CPC 1480 is a quadrangular fragment that corresponds to a middle portion of the right maxilla. The external surface bears pits, grooves, and rounded edges; the ventral surface is slightly rugose, which suggests the periosteum is lost. The internal structure of the maxilla is visible at a transverse break at the anterior end of the specimen. The bone is compact and is perforated by some vascular channels.

CPC 1481 is a fragment of the posterior part of the left maxilla, and like CPG 1479 and CPG 1480 , it has deep pits and grooves on its external surface. The ventral surface is slightly rugose and, on the medial margin, has transverse grooves indicating the sutural surface for the nasal (Figure 4C). CPC 1482 is a small portion of the left dentary, $10.3 \mathrm{~mm}$ in length (Figure 4D). In transverse view it has a semitriangular shape. The external surface is ornamented with small pits and grooves. Two oval vascular foramina are present on the laterodorsal surface. Three alveoli are preserved. Of the tree preserved alveoli the middle is the only complete one. All the alveoli are semicircular in outline and are nearly confluent. The medial 
surface of the dentary is flat and bears longitudinal striations indicating the contact surface for the splenial. The semitriangular shape and the evidence of the contact with the splenial suggest that it is the anterior portion of the mandible.

CPC 1489 is a procoelous vertebral centrum lacking the neural arch (Figures 5A and 5B). The anterior surface is damaged, and the anterior socket of the centrum is not visible. The size of CPC 1489 (length $=19.84 \mathrm{~mm}$, anterior width $=12.30 \mathrm{~mm}$, posterior width $=13.21 \mathrm{~mm}$ ) indicates a small animal, probably $1.5 \mathrm{~m}$ total length.

CPC 1490 is a small procoelous vertebral centrum (length $=12.11 \mathrm{~mm}$, anterior width $=13.31 \mathrm{~mm}$, posterior width $=9.97 \mathrm{~mm}$ ). The position of the vertebra is uncertain. The neural arch is not preserved. The centrum is wider than high (Figures $5 \mathrm{C}$ and $5 \mathrm{D})$. The central part of the neurocentral suture surface is exposed and rugose.

CPC 1484 is a quadrangular paravertebral osteoderm with a surface ornamented with pits and grooves. It bears a small anteromedial longitudinally running keel. The ventral surface is planar and has fiber marks (Figures $5 \mathrm{E}$ and $5 \mathrm{~F}$ ).

CPC 1485 is a paravertebral osteoderm with a rectangular outline. The dorsal surface is ornamented with pits and grooves. The ventral surface has fiber marks and four foramina (Figures $5 \mathrm{G}$ and $5 \mathrm{H}$ ).
CPG 1486 (Figure 5I and 5J) and CPG 1487 (Figures $5 \mathrm{~K}$ and $5 \mathrm{~L}$ ) are lateral dorsal osteoderms with a rounded shape. They are sculpted with large pits and grooves. The internal face is planar in both osteoderms, but CPC 1486 has several foramina.

\section{Discussion}

\subsection{TAXONOMY DETERMINATION}

Among North American crocodilians, only Alligatoroidea includes taxa with bulbous teeth, and these form the clade Globidonta (Brochu, 1999). The crocodilian specimen CPG 1483 from La Parrita locality can be referred to globidontan alligatorid based upon inflated tooth shape. An accurate determination to genus or species level based upon the isolated tooth is impossible, because the teeth of North American Late Gretaceous basal globidontans Brachychampsa, Stangerochampsa and Albertochampsa, resemble each other (Carbot-Chanona, 2014). In all of them, the teeth are striated and inflated with oval cross sections, similar to CPC 1483. Only the posterior teeth of the globidontan Bottosaurus, presently known only from eastern North America, can be differentiated from those of Stangerochampsa, Albertochampsa and

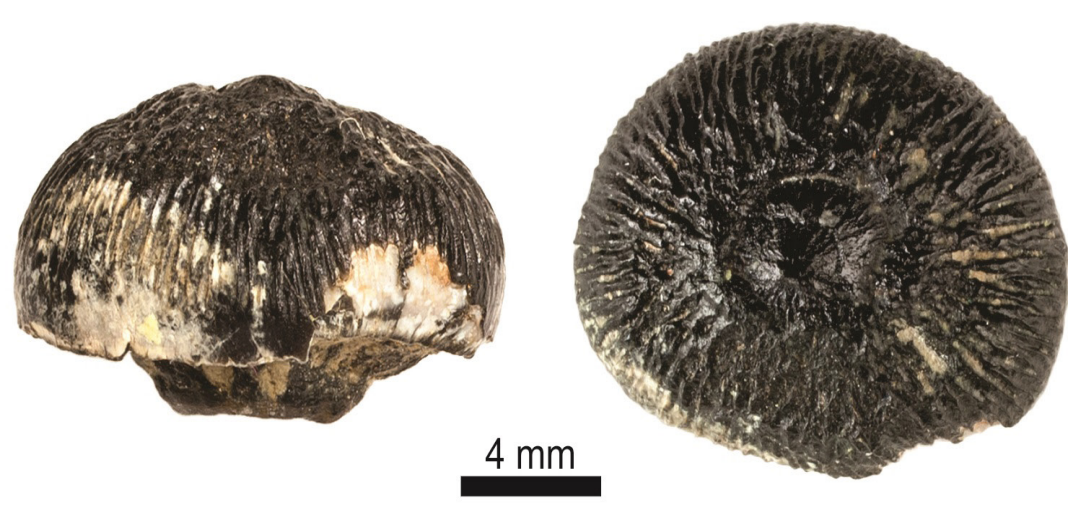

A
B

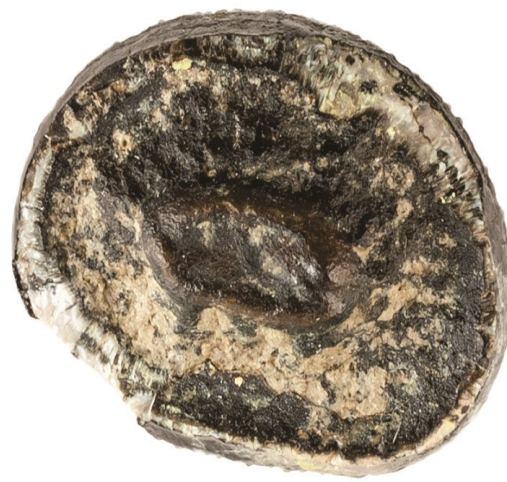

C

Figure 3 Globidontan alligatoroid from La Parrita site, Cerro del Pueblo Formation. CPC 1483, isolated posterior tooth in lateral (A), apical (B) and basal (C) view. 
Brachychampsa, because the teeth are laterally compressed and have strong striations that give a wrinkled appearance (Erickson, 1998).

Previously, crocodilian material from Cerro del Pueblo Formation was referred to as Brachychampsa montana by Aguillon-Martinez (2010), although the identification should be treated with caution, and be referred as Brachychampsa sp., or even better, only as Globidonta, due to the lack of diagnostic characters. In consequence, the crocodyliform specimen from La Parrita, is the second record of a globidontan alligatoroid from the Cerro del Pueblo Formation, extending the geographical record of this taxon in North America and increasing the crocodilian diversity in the Late Cretaceous of Mexico.

On the other hand, the vertebrae CPC 1489 and CPC 1490 described in this work can only be referred to Eusuchia based on the strong procoely of the centrum, which characterizes the advanced eusuchian forms, including Crocodylia (Benton and Clark, 1988; Brochu, 1997; Molnar et al., 2015). The neurocentral suture surface exposed in

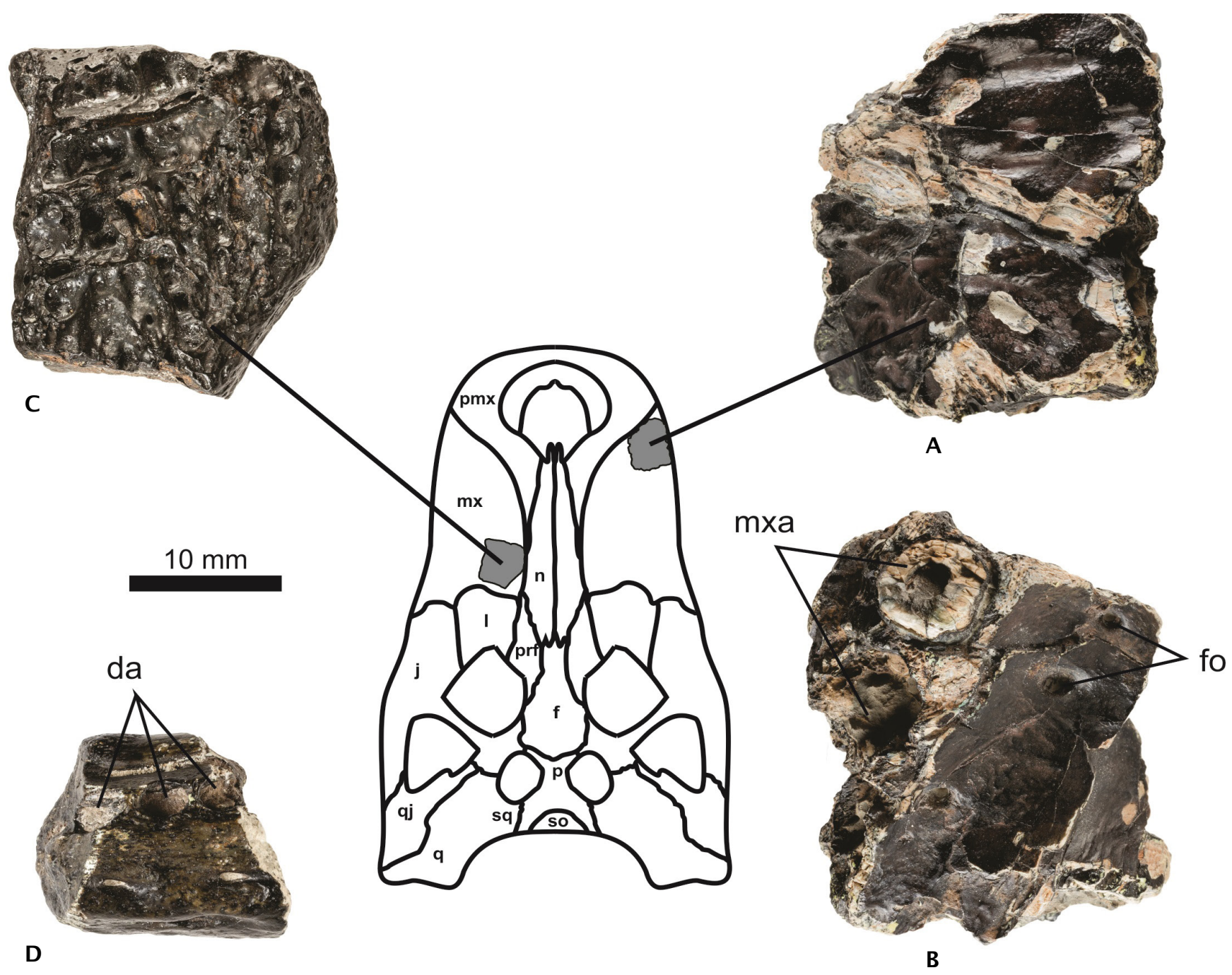

Figure 4 Eusuchia indeterminated from the La Parrita site, Cerro del Pueblo Formation. Skull and mandibular elements: CPC 1479, anterolateral portion of right maxilla in dorsal (A) and ventral (B) view; CPC 1481, fragment of left maxilla in dorsal (C) view, and CPC 1482, fragment of left dentary (D). Abbreviations: da, dentary alveolus; fo, foramen; mxa, maxillary alveolus.. 
the vertebra CPC 1490 is indicative of a non-adult specimen, because in crocodilians closure of neurocentral sutures in cervical vertebrae happens in large individuals (Brochu, 1996). In the same way, the general shape of the osteoderms, as well as the presence of a keel in CPC 1484, allow referred the osteoderms to Eusuchia level.

\subsection{PALEOENVIRONMENTAL SIGNIFICANGE}

Temperature is the principal influence on global distribution of extant crocodilians (Marwick, 1998). Recent studies show that crocodilians are good ecosystem indicators (Mazzotti et al., 2009). In consequence, it is possible to use fossil crocodilians as paleoclimatic indicators. Recent members of the Alligatoridea are intolerant to salt water because they lack salt glands (Taplin et al., 1982). Consequently, the extant alligators cannot live in estuaries or coastal areas.

The association of charophyte oogonia with globidontan alligatoroid, as well as dinosaurs at La Parrita, provides evidence for fluviolacustrine environments on a delta plain (Vogt et al., 2016) and a tropical climate. Mud cracks, interpreted here as desiccation cracks, repeatedly found on the surfaces of sandstone layers at Las Águilas, also suggest terrestrial or even subaerial conditions.

The vast majority of vertebrate remains at La Parrita are fragments or isolated bones that may occur isolated in the sandy layers, or in taxonomically mixed surface clusters, covering an area of a few up to about $100 \mathrm{~m}^{2}$. The size of the specimens ranges between 0.5 $\mathrm{mm}$ up to about $150 \mathrm{~mm}$. These concentrations were likely assembled in depressions or channels that were permanently or frequently flooded, and contain a remarkable amount of crocodilian material.

The vertebrate and invertebrate assemblages as well as plant material and sedimentary structures in the Cerro del Pueblo Formation suggest deposition in multiple stacked channelized sand bodies on a permanently changing delta plain (Vogt et al., 2016). The depositional setting was influenced by cyclically fluctuating paleoenvironments of intermittent shal- low marine, brackish to fresh water, or even subaerial conditions. The abundance of oysters throughout the measured section indicates frequent mixing of salt and fresh water, generating a changing zone of brackish environments (Vogt et al., 2016).

\section{Conclusions}

We recognize the presence of the first evidence of globidont alligatorid specimen from La Parrita locality, Cerro del Pueblo Formation, based in the morphology of an isolated tooth. This extended the geographical record of Globidonta in North America. The vertebrae and osteoderms are be referred to Eusuchia, due to the lack of morphological characters to genus or species level determination, but are important because the Mesozoic record of crocodyliforms in Mexico is scarce.

A mixture of depositional environments exists at La Parrita. The oscillating sequence of sandstones and siltstones suggests deposition under brackish conditions. The presence of oyster banks, abundant bivalves, ammonites, gastropods, and marine vertebrates (sharks and mosasauroids) indicate shallow marine environments. On the other hand, continental to brackish to fresh water conditions is indicated by characean oogonids, vascular plants, shell fragments of trionychid turtles, crocodyliforms and dinosaurs (e.g., Meyer et al., 2008).

\section{Acknowledgements}

Lucía Alfaro Ortíz, Isaí Oyervidez Salazar, and Zaira Casas are acknowledged for their support to this project. We are grateful to the Museo del Desierto and its chairman Arturo González for supporting this investigation. GCG thanks the Wikipaleo group for sharing bibliography, and 

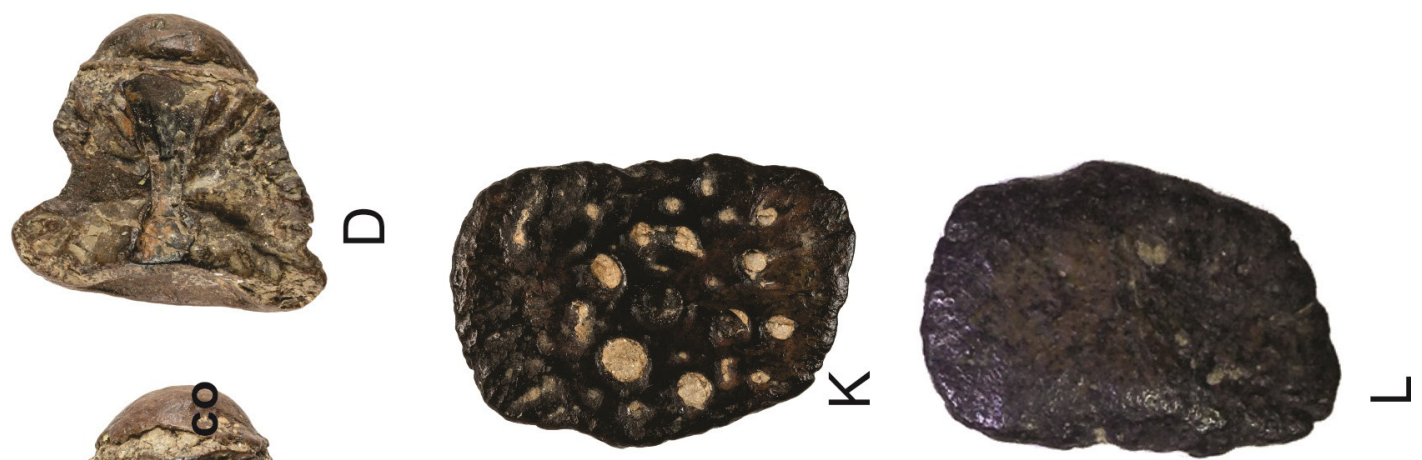

$\widehat{\underline{0}} \hat{\subseteq}$.

预

응 过

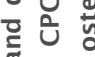

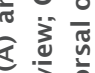

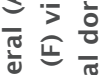

莫

$\leq$ 당

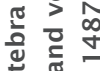

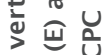

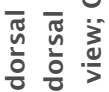
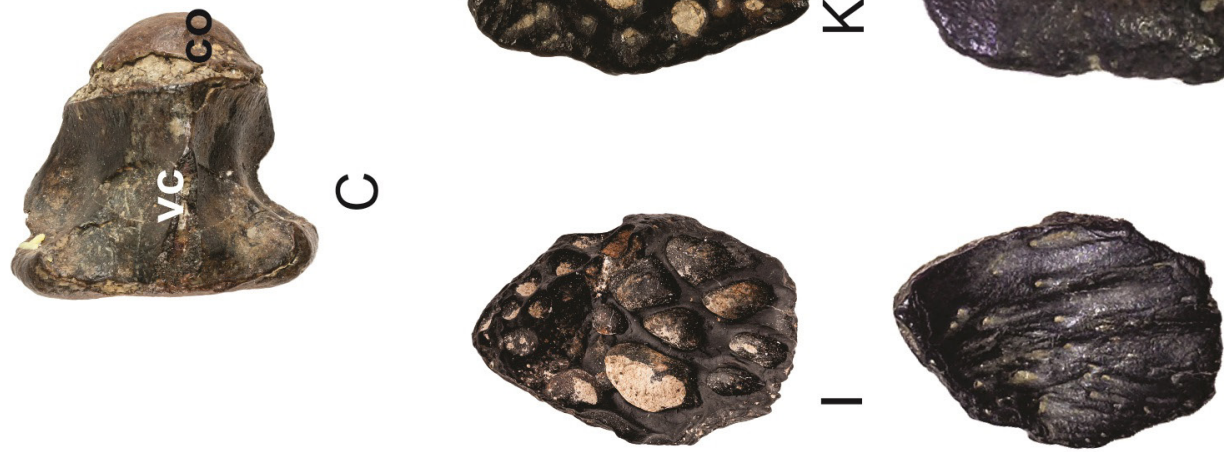

오

$\stackrel{\infty}{\dot{y}} \overline{\mathrm{c}}$

u

U⿺ จ

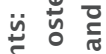

ฮิ

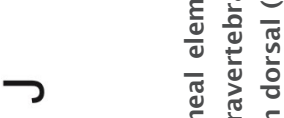

ฮ

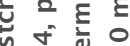

นิ용

늘

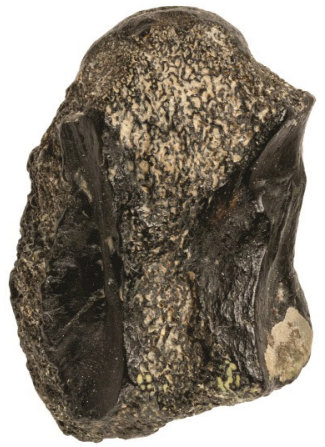

$m$
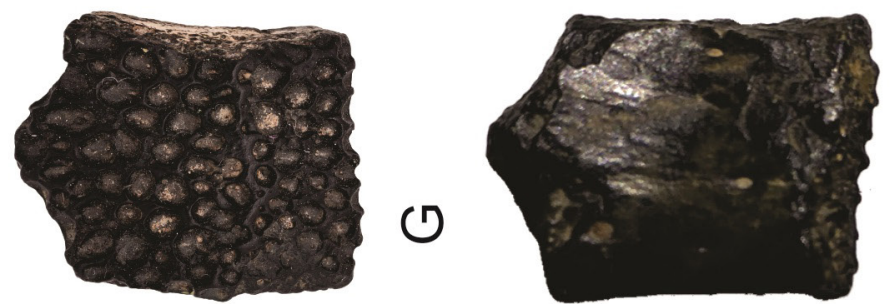

类

항ㅎㅇ

응 อิำ

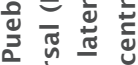

0

I

व 흉 क्ष

원

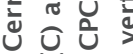

ब

ज证

(1)

론 全



ฮ

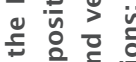

年

은 跑

造产

둥

ह

ये

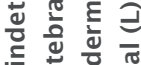

放

टे के गे

जै बำ

岀记




Luis Enrique Gómez-Pérez who took the photographs, and especially Christopher Brochu (University of Iowa) for comments on an early version and English review. We also thank José Rubén Guzman-Gutiérrez and Eberhard "Dino" Frey for review and suggestions, and Francisco J. Vega for editorial support.

\section{References}

Aguillon-Martinez, M.C., 2010, Fossil vertebrates from the Cerro del Pueblo Formation, Coahuila, Mexico, and the distribution of Late Campanian (Cretaceous) terrestrial vertebrate faunas: Dallas, Texas, Southern Methodist University, master thesis, 135 p.

Benton, M.J., Clark, J.M., 1988, Archosaur phylogeny and the Crocodylia, in Benton, M.J. (ed.), The phylogeny and classification of the tetrapods: Oxford, Clarendon Press, 295-338.

Brinkman, D.B, 2014, Turtles of the Mesozoic of Mexico, in Rivera-Sylva, H.E., Frey, E., Brickman, D. (eds.), Dinosaurs and other reptiles from the Mesozoic of Mexico: Bloomington, Indiana University Press, $30-43$.

Brochu, C.A., 1996, Closure of neurocentral sutures during crocodilian ontogeny: implications for maturity assessment in fossil archosaurs: Journal of Vertebrate Paleontology, 16(1), 4962. https://doi.org/10.1080/02724634.1996 .10011283

Bochu, C.A., 1997, Morphology, fossils, divergence timing, and the phylogenetic relationships of Gavialis: Systematic Biology, 46(3), 479-522. https://doi.org/10.2307/2413693

Brochu, C.A., 1999, Phylogenetics, taxonomy, and historical biogeography of Alligatoroidea: Journal of Vertebrate Paleontology, Memoir 6, Supplement to Number 2, 9-100. https:// doi.org/10.1080/02724634.1999.10011201
Brochu, C.A., 2004, Alligatorine phylogeny and the status of Allognathosuchus Mook, 1921: Journal of Vertebrate Paleontology, 24(4), 857-873. https://doi.org/10.1671/0272$4634(2004) 024$ [085 7:a patso]2.0. co;2

Brochu, C.A., 2011, Phylogenetic relationships of Necrosuchusionensis Simpson, 1937 and the early history of caimanines: Zoological Journal of the Linnean Society, 163, S228-S256. https:/ / doi.org/10.1111/j.1096-3642.2011.00716.x

Bryant, L.J., 1989, Non-dinosaurian lower vertebrates across the Cretaceous-Tertiary boundary in northeastern Montana: University of California Publications in Geological Sciences, 134, 1-107.

Carbot-Chanona, G., 2014, Overwiew of Mesozoic crocodyliforms from Mexico, in Rivera-, Sylva, H.E., Frey, E., Brickman, D. (eds.), Dinosaurs and other reptiles from the Mesozoic of Mexico: Bloomington, Indiana University Press, 110-125.

Carpenter, K., Lindsay, D., 1980, The dentary of Brachychampsa montana Gilmore (Alligatorinae; Crocodylidae), a Late Cretaceous turtleeating alligator: Journal of Paleontology, 54(6), 1213-1217.

Eberth, D.A., Delgado-de Jesús, C.T., Lerbekmo, J.F., Brinkman, D.B., Rodríguez-de la Rosa, R.A., Sampson, S.D., 2004, Cerro del Pueblo Fm (Difunta Group, Upper Cretaceous), Parras Basin, southern Coahuila, Mexico: reference sections, age, and coorrelation: Revista Mexicana de Ciencias Geológicas, 21(3), 335-352.

Erickson, B.R., 1972, Albertochampsa langstoni, gen. et. sp. nov., a new alligator from the Cretaceous of Alberta: Scientific Publications of the Science Museum of Minnesota, 2(1), $1-13$.

Erickson, B.R., 1998, Crocodilians of the Black Mingo Group (Paleocene) of the South Carolina Coastal Plain, in Sanders A.E. 
(ed.), Paleobiology of the Williamsburg Formation (Black Mingo Group; Paleocene) of South Carolina, U.S.A.: Transactions of the American Philosophical Society, 88(4), 196-214

Frey, E., Stinnesbeck, W., 2014, Mexican pterosaurs - Rare jewels in the fossil record, in Rivera-Sylva, H.E., Frey, E., Brickman, D. (eds.), Dinosaurs and other reptiles from the Mesozoic of Mexico: Bloomington, Indiana University Press, 126-142.

Gilmore, C.W., 1911, A new fossil alligator from the Hell Creek beds of Montana: Proceedings of the United States National Museum, 41, 297-301. https://doi.org/10.5479/ si.00963801.41-1860.297

Gray, J.E., 1844, Catalogue of the tortoises, crocodilians, and amphisbaenians in the Collection of the British Museum: London, British Museum (Natural History), 80 p.

Hastings, A.K., Reisser, M., Scheyer, T.M., 2016, Character evolution and the origin of Caimaninae (Crocodylia) in the New World Tropics: new evidence from the Miocene of Panama and Venezuela: Journal of Paleontology, 90(2), 317-332. https://doi. org/10.1017/jpa.2016.37

Hill, J.A., 1988, Sedimentology of delta-front sandstones, Cerro del Pueblo Formation (Upper Cretaceous), Parras Basin, Coahuila, Mexico: New Orleans, Louisiana, University of New Orleans, master thesis, $163 \mathrm{p}$.

Huxley, T.H., 1875, On Stagonolepis robertsoni, and on the evolution of the Crocodilia: QuaternalyJournal of the Geological Society, 31: 423-438. https://doi.org/10.1144/gsl. jgs. 1875.031.01-04.29

Irmis, R.B., Hutchison, J.H., Sertich, J.J.W., Titus, A.L., 2013, Crocodyliforms from the Late Cretaceous of Grand Staircase-Escalante National Monument and vicinity, southern Utah, U.S.A, in Titus, A.L., Loewen, M.A. (eds.), At the top of the Grand Staircase:
The Late Cretaceous of southern Utah: Bloomington, Indiana University Press, 424-444.

Martin,J.E., Lauprasert, K., 2010, A new primitive alligatorine from the Eocene of Thailand: relevance of Asiatic members to the radiation of the group: Zoological Journal of the Linnean Society, 158, 608-628. https://doi. org/10.1111/j.1096-3642.2009.00582.x

Marwick, P.J., 1998, Fossil crocodilians as indicators of Late Cretaceous and Cenozoic climates: implications for using palaeontological data in reconstructing palaeoclimate: Palaeogeography, Palaeoclimatology, Palaeoecology, 137, 205-271. https://doi. org/10.1016/s0031-0182(97)00108-9

Mazzotti, F.J., Ronnie Best, G., Brandt, L.A., Cherkiss, M.S., Jeffrey, B.M., Rice, K.G., 2009, Alligators and crocodiles as indicators for restoration of Everglades ecosystems: Ecological Indicators, 9(6), S137-S149. https://doi.org/10.1016/j. ecolind.2008.06.008

McBride, E.F., 1974, Significance of color in red, green, purple, olive, brown, and gray beds of Difunta Group, northeastern Mexico: Journal of Sedimentary Petrology, 44(3), 760773. https://doi.org/10.1306/212f6b9a2b24-11d7-8648000102c1865d

Meyer, C.A., Frey, E., Thürring, B., 2008, The pitfalls of interpreting incomplete dinosaurs trackways - an example of a dromeosaurid trackway from the Late Cretaceous of the Sierra Madre Oriental (Cerro del Pueblo Formation, Late Campanian; Parras Basin, Coahuila, NE Mexico) (abstract), in 6th Meeting of the European Association of Vertebrate Paleontologist: Spišská Nová Ves, Slovak Republic, 69-73.

Molnar, J.L., Pierce, S.E., Bhullar, B.-A.S., Turner, A.H., Hutchinson, J.R., 2015, Morphological and functional changes in the vertebral column with increasing aquatic 
adaptation in crocodylomorphs: Royal Society Open Science, 2, 150439. http:// dx.doi. org/10.1098/rsos.150439

Monroy Mújica, I.H., 2009, Microvertebrados fósiles cretácicos tardíos (Campaniano Tardío) de la Formación Aguja en el Noroeste de Coahuila, México: México D.F., Facultad de Estudios Superiores Iztacala, Universidad Nacional Autónoma de México, bachelor thesis, 111 pp.

Norell, M.A., Clark, J.M., Hutchison, J.H., 1994, The Late Cretaceous alligatoroid Brachychampsa montana (Crocodylia): New material and putative relationships: American Museum Novitates, 31 16, 1-26.

Obradovich, J.D., 1993, A Cretaceous time scale, in Caldwell, W.G.E., Kawfman, G.E., (eds.), Evolution of the Western Interior Basin: Canadian Association of Geologists, Special Paper 39, 379-396.

Owen, R., 1842, Report on British fossil reptiles, Part II: Report of the British Association for the Advancement of Science for 1841, 11, 60-204.

Rivera-Sylva, H.E., Carpenter, K., 2014a, Saurischian dinosaurs from Mexico, in Rivera-Sylva, H.E., Carpenter, K., Frey, E. (eds), Dinosaurs and other reptiles from the Mesozoic from Mexico: Bloomington, Indiana University Press, 143-155.

Rivera-Sylva, H.E., Carpenter, K., 2014b, Ornithischian dinosaurs from Mexico, in Rivera-Sylva, H.E., Carpenter, K., Frey, E., (eds), Dinosaurs and other reptiles from the Mesozoic from Mexico: Bloomington, Indiana University Press, 156-180.

Rodríguez-de la Rosa, R.A., Cevallos-Ferriz, S.R.S., 1998, Vertebrates of the El Pelillal locality (Campanian, Cerro del Pueblo Formation), southeastern Coahuila, Mexico: Journal of Vertebrate Paleontology, 18(4), 751-764. https://doi.org/10.1080/02724634.1998.10 011104
Salas-Gismondi, R., Flynn, J.J., Baby, P., TejadaLara, J.V., Wesselingh, F.P., Antoine, P.-O., 2015, A Miocene hyperdiverse crocodilian community reveals peculiar trophic dynamics in proto-Amazonian mega-wetlands. Proceedings of the Royal Society B, 282, 20142490. http://dx.doi.org/10.1098/ rspb.2014.2490

Skutchas, P.P., Danilov, I.G., Kodrul, T.M., Jin, J., 2014, The first discovery of an alligatorid (Crocodylia, Alligatoroidea, Alligatoridae) in the Eocene of China: Journal of Vertebrate Paleontology, 34(2), 471-476. https://doi.org /10.1080/02724634.2013.809725

Stinnesbeck, W., Frey, E., 2014, Paleogeography and paleoenvironment of Mexico during the Mesozoic, in Rivera-Sylva, H.E., Frey, E., Brickman, D. (eds.), Dinosaurs and other reptiles from the Mesozoic of Mexico: Bloomington, Indiana University Press, 13-29.

Sullivan, M., Lucas, S.G., 2003, Brachychampsa montana Gilmore (Crocodylia, Alligatoroidea) from the Kirtland Formation (Upper Campanian), San Juan Basin, New Mexico: Journal of Vertebrate Paleontology, 23(4), 832-841. https://doi.org/10.1671/a1082-8

Taplin, L.E., Grigg, G.C., Harlow, P., Ellis, T.M., Dunson, W.A., 1982, Lingual salt glands in Crocodylus acutus and C. johnstoni and their absence from Alligator mississipiensis and Caiman crocodilus: Journal of Comparative Physiology B, 149, 43-47. https://doi.org/10.1007/ bf00735713

Vivas-González, R., 2013, Paleoecología de dinosaurios hadrosauridos (Ornithischia: Ornithopoda) de la Formación Cerro del Pueblo (Cretácico Tardío: Campaniano), Coahuila, México: Linares, Nuevo León, Universidad Autónoma de Nuevo León, master thesis, $102 \mathrm{p}$.

Vogt, M., Stinnesbeck, W., Zell, P., Kober, B., Kontny, J., Herzer, N., Frey, E., Rivera-Sylva, H.E., Padilla Gutiérrez, J.M., Amezcua Torres, N., 
Flores Huerta, D., 2016, Age and depositional environment of the "dinosaur graveyard" at Las Aguilas, southern Coahuila, NE Mexico: Palaeogeography, Palaeoclimatology, Palaeoecology, 441(1), 758-769. https://doi. org/10.1016/j.palaeo.2015.10.020

Williamson, T.E., 1996, ?Brachychampsa sealeyi, sp. nov. (Crocodylia, Alligatoroidea) from the Upper Cretaceous (lower Campanian)
Menefee Formation, northwestern New

Mexico: Journal of Vertebrate Paleontology, 16(3), 421-431. https://doi.org/10.1080/02 724634.1996.10011331

Wu, X.-C., Brinkman, D.B., Rusell, A.P., 1996, A new alligator from the Upper Cretaceous of Canada and the relationships of early eusuchians: Palaeontology, 39(2), 351-375. 